\title{
Letter \\ Fibromyalgia and sleep-disordered breathing: the missing link
}

\section{Denis Martinez and Cristiane Maria Cassol}

Division of Cardiology, Hospital de Clinicas de Porto Alegre, Universidade Federal do Rio Grande do Sul, Rua Ramiro Barcelos, 2350 - Porto Alegre, RS - Brazil - 90035-903

Corresponding author: Cristiane Maria Cassol, ccassol@hcpa.ufrgs.br

Published: 25 November 2008

This article is online at http://arthritis-research.com/content/10/6/408

(c) 2008 BioMed Central Ltd

Arthritis Research \& Therapy 2008, 10:408 (doi:10.1186/ar2538)

See related review articles by Martinez-Lavin, http://arthritis-research.com/content/9/4/216, and Staud, http://arthritis-research.com/content/8/3/208, related research article by Vargas-Alarcón, http://arthritis-research.com/content/9/5/R110, related editorial by Eisinger,

http://arthritis-research.com/content/9/4/105, related letter by Felix and Fontenele, http://arthritis-research.com/content/9/5/404, and related response by Eisinger, http://arthritis-research.com/content/10/6/409

Recently, Martinez-Lavin [1] proposed a model of sympathetically maintained neuropathic pain syndrome that has the merit of scrutinizing possible mechanisms behind the central sensitization model [2]. Eisinger [3], in an editorial comment, raises the issue of heterogeneity permeating Martinez-Lavin's proposition. Since it is difficult to establish a traumatic trigger event in all cases, Eisinger considers multicausality as more reasonable than a single post-traumatic etiology for all cases. Félix and Fontenele [4] further explored this venue, speculating that the orthostatic intolerance symptoms seen in the majority of fibromyalgia patients are a consequence of sympathetic hyperactivity. The idea that a COMT val-158-met polymorphism may cause higher cathecolamine levels has been explored [5]. Loevinger and colleagues [6] have shown that the metabolic syndrome is more common in individuals with fibromyalgia who also have higher body mass index, blood pressure, and waist-to-hip ratio than controls.

Interestingly, elevated body mass index, blood pressure, and waist-to-hip ratio are associated with sleep-disordered breathing. We recently reported in a study that $50 \%$ of the women with obstructive sleep apnea syndrome or upper airway resistance syndrome had chronic pain and more than 11 tender points when pressed with $4 \mathrm{kgf} / \mathrm{cm}^{2}$ [7]. Guilleminault and colleagues [8] reported orthostatic intolerance in patients with upper airway resistance syndrome. We believe that the authors investigating this theme should discuss the possibility of sleep-disordered breathing being the missing link between fibromyalgia, pain, disturbed sleep, alpha-delta sleep, hypotension, sympathetic hyperactivity, and metabolic syndrome.

We are conducting investigations into whether exposition to the typical stress of sleep-disordered breathing - with repeated arousal episodes and hypoxemia - has fibromyalgia as a possible outcome. Our preliminary results underline the need to consider and further explore this hypothesis.

\section{Competing interests}

The authors declare that they have no competing interests.

\section{References}

1. Martinez-Lavin M: Biology and therapy of fibromyalgia: Stress, the stress response system, and fibromyalgia. Arthritis Res Ther 2007, 9:216.

2. Staud R: Biology and therapy of fibromyalgia: pain in fibromyalgia syndrome. Arthritis Res Ther 2006, 8:208.

3. Eisinger J: Dysautonomia, fibromyalgia and reflex dystrophy. Arthritis Res Ther 2007, 9:105.

4. Félix FHC, Fontenele JB: Is fibromyalgia a cardiovascular disease? A comment on Martinez-Lavin's review 'Stress, the stress response system, and fibromyalgia'. Arthritis Res Ther 2007, 9:404.

5. Vargas-Alarcón G, Fragoso JM, Cruz-Robles D, Vargas A, Vargas A, Lao-Villadóniga Jl, García-Fructuoso F, Ramos-Kuri M, Hernández F, Springall R, Bojalil R, Vallejo M, Martínez-Lavín M: Catechol-O-methyltransferase gene haplotypes in Mexican and Spanish patients with fibromyalgia. Arthritis Res Ther 2007, 9: R110.

6. Loevinger BL, Muller D, Alonso C, Coe CL: Metabolic syndrome in women with chronic pain. Metabol Clin Exp 2007, 56:87-93.

7. Germanowicz D, Lumertz MS, Martinez D, Margarites AF: Coexistência de transtornos respiratórios do sono e síndrome fibromiálgica. J Bras Pneumol 2006, 32:333-338.

8. Guilleminault C, Faul JL, Stoohs R: Sleep-disordered breathing and hypotension. Am J Respir Crit Care Med 2001, 164:12421247. 